\title{
The influence of probiotic bacteria and human gut microorganisms causing opportunistic infections on Blastocystis ST3
}

\author{
M. Lepczyńska* (i] and E. Dzika(1)
}

\begin{abstract}
Background: Blastocystis subtype 3 is an intestinal protist present in humans throughout the world with a controversial pathogenic potential. It has been suggested that probiotic bacteria inhibit the multiplication of gut protozoans, while others are beneficial for their development. This study aimed to evaluate the efficacy of the lactic acid bacteria Lactobacillus rhamnosus, Lactococcus lactis and Enterococcus faecium in Blastocystis ST3 eradication and the relevance of the intestinal microorganisms Escherichia coli, Candida albicans and Candida glabrata in protozoan proliferation. Blastocystis xenic and axenic culture was co-incubated with the above-mentioned microorganisms and their cell free supernatants at different concentrations in vitro. The number of protozoan cells was counted every day.

Results: Both experiments, with xenic and axenic cultures, showed Blastocystis inhibition by L. rhamnosus and L. lactis and their supernatants from the 2 nd day of co-incubation. Furthermore, co-incubation with both $E$. faecium and $E$. coli showed a beneficial influence on Blastocystis during the first 2 days. Only after 3 days did the above-mentioned bacteria start to inhibit Blastocystis growth in both cultures. The supernatant containing the metabolites of E. coli was effective to a lesser degree. Compared to the control samples, co-incubation with both C. albicans and C. glabrata showed a faster decrease in Blastocystis proliferation, but this was not statistically significant.

Conclusions: This study has shown the potential of using L. rhamnosus and L. lactis, as well as E. faecium as a prophylactic treatment against Blastocystis colonization or as an additional treatment regimen in combination with standard drugs.
\end{abstract}

Keywords: Blastocystis, Subtype 3, Eradication, Probiotics, Gut microbiota

\section{Background}

Blastocystis is a protist present throughout the world in the intestines of both healthy and symptomatic humans and animals $[1,2]$. Its pathogenic potential is still controversial. This unicellular microorganism causes gastrointestinal as well as skin disorders [3, 4]. Seventeen morphologically indistinguishable subtypes have been identified based on an analysis of a small subunit rDNA (SSU rRNA) gene sequence among Blastocystis isolated from humans and animals. It has been suggested that

\footnotetext{
*Correspondence: malgorzata.lepczynska@uwm.edu.pl Department of Medical Biology, Faculty of Health Sciences, Collegium Medicum, University of Warmia and Mazury, Żołnierska 14C,
} 10-561 Olsztyn, Poland
ST3 may be the only subtype (ST) of human origin [5]. That is why this subtype was chosen for analysis in this study. The fecal-oral route is most likely the main mode of transmission. Children, the elderly and immunocompromised individuals appear to be highly susceptible to Blastocystis invasion [6], while other researchers have suggested that people between 30 and 50 years of age are most prone to being infected by Blastocystis [7-10]. In the recent literature, researchers have been discussing the correlation between different Blastocystis subtypes and their pathogenic potential. The explanations for pathogenicity may include intra-subtype variations in Blastocystis protease activity, or differences in the intestinal microbiota of the individual host, which can interact to mediate host colonization and Blastocystis virulence 
$[11,12]$. Recently, it has been found that the presence of gut microbiota seems to be essential for the pathogenic expression of enteric protozoan such as Blastocystis. Berrilli et al. [13] suggest the hypothesis that some intestinal bacteria inhibit multiplication of gut protozoa.

A 2014 study by Nourrisson et al. [14] and a 2016 study by Nagel et al. [15] suggest that Blastocystis may be used as an indicator of microbiota changes-a lower abundance of Faecalibacterium prausnitzii and Bifidobacterium spp. was reported to lead to the intestinal dysbiosis. On the other hand, in 2016, Audebert et al. [16] suggested that colonization by Blastocystis could be associated with healthy gut microbiota. Their study showed a higher bacterial diversity in Blastocystis-colonized patients compared to that identified in Blastocystis-free individuals. However, the same study showed an increasing level of the Lactobacillaceae family in patients not colonized by Blastocystis. Many researchers have reported on the inhibition of a wide range of pathogenic microorganisms like Giardia sp., Entamoeba histolytica, Eimeria sp. or Cryptosporidium parvum by probiotic bacteria [17-23]. Also there have been previous studies which have shown the effects of certain probiotic yeasts-Saccharomyces boulardii on Blastocystis development [24].

The most recent results of the latest studies leave the pathogenicity of Blastocystis still unclear. Researchers still do not know if Blastocystis is an agent of gut dysbiosis and is responsible for changing the microbiotic diversity, or if the metabolic dysfunctions and changes in the content of microbiota are the reason for the higher colonization by Blastocystis. There is a possibility that some species of bacteria are creating the conditions for Blastocystis colonization in the gut. It may also depend on the parasitic subtype [16].

The World Health Organization (WHO) defines probiotics as "live organisms which when administered in adequate amounts confer a health benefit to the host" [25]. As an alternative bio-therapeutic for giardiosis, amoebiasis or cryptosporidiosis, there are a number of studies which have been conducted. In our study, we have aimed to explore the inhibitory effect of 3 different probiotics and 3 species causing opportunistic infections on Blastocystis proliferation for the first time.

\section{Materials and methods}

\section{Blastocystis cultures}

Blastocystis subtype 3 was kindly provided by C. Rune Stensvold (Statens Serum Institute, Copenhagen, Denmark) and cultured in modified Jones' medium $(\mathrm{pH}=7.1)$ [mix of $93.8 \mathrm{~mL} \mathrm{Na} \mathrm{HPO}_{4}-9.46 \mathrm{~g} / \mathrm{L}$ of dis-

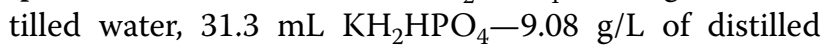
water, $562.5 \mathrm{NaCl}-9 \mathrm{~g} / \mathrm{L}$ of distilled water, $0.1 \%$ of yeast extract (Oxoid, UK)] supplemented with 10\% horse serum (Sigma-Aldrich, USA) $[26,27]$ at $37{ }^{\circ} \mathrm{C}$ in tightly closed polypropylene $12 \mathrm{~mL}$ Falcon tubes, in anaerobic conditions. Because the experiment was performed in two ways, two versions of Blastocystis culture-xenic and axenic were conducted. The xenic culture (containing bacteria from the patient gut) was subcultured every 2-3 days. The axenic culture (without bacteria) was obtained by supplementation with $100 \mathrm{UI} / \mathrm{mL}$ penicillin and $100 \mu \mathrm{g} / \mathrm{mL}$ streptomycin (Sigma-Aldrich, USA) and incubated for 3-4 days. The cultures were then screened using standard microscopy [28].

\section{Bacterial and fungal isolates and growth conditions}

A lyophilized stock of the organisms was obtained from the American Type Culture Collection (ATCC). The commensal bacteria Lactobacillus rhamnosus (ATCC 7469), Lactococcus lactis (ATCC 11454), Enterococcus faecium (ATCC 6057), and the microorganisms causing opportunistic infections Escherichia coli (ATCC 25922) as well as Candida albicans (ATCC 64548) and Candida glabrata (ATCC 15126) isolates were used in the present study. All isolates were previously purchased in MicroSwab form from Merck (Warsaw, Poland). The bacterial and fungal isolates were freshly cultivated on Tryptone Soy Broth (TSB) (Merck, Poland) before the experiments and also stored in TSB with $20 \%$ glycerol at $-70{ }^{\circ} \mathrm{C}$ until needed. The bacteria were routinely cultured on TSB (pH 7.3) for 2 days at $37^{\circ} \mathrm{C}$ and the fungi were cultured on Sabouraud broth (pH 5.8) for 6 days at $24.5^{\circ} \mathrm{C}$. Sabouraud broth contains mycological peptone $(10 \mathrm{~g} / \mathrm{L})$, glucose $(20 \mathrm{~g} / \mathrm{L})$. All of the microorganisms were incubated in tightly closed polypropylene $12 \mathrm{~mL}$ Falcon tubes, in anaerobic conditions.

\section{Bacteria preparation}

Each isolate of bacteria was harvested by centrifugation $(5525 \times \mathrm{g}, 15 \mathrm{~min})$ from TSB after 2 days of incubation and washed three times with sterile PBS (phosphate buffered saline, $\mathrm{pH}$ 7.0). The pellet was suspended in sterile Jones' medium $[26,27]$. The optical density $\left(\mathrm{OD}^{620}\right)$ of the bacterial suspensions was adjusted to $0.5 \pm 0.06,1.0 \pm 0.06$, and $1.5 \pm 0.06$ in Jones' medium. Aliquots of the bacterial suspensions were diluted to 1:100, 1:1000, 1:10000 with PBS. $50 \mu \mathrm{L}$ from each dilution was spread on Tryptone Soy Agar (TSA) plates. Plates were incubated at $37^{\circ} \mathrm{C}$ for 2 to 4 days and colonies counted. Final concentrations of bacterial suspensions are presented in Table 1.

\section{Fungi preparation}

Two isolates of fungi, Candida albicans and Candida glabrata, were harvested by centrifugation at $2300 \times g$ for $10 \mathrm{~min}$ and washed three times in sterile PBS. Subsequently, the fungi were concentrated into pellet form 
Table 1 Concentrations of microorganisms used to the experiment

\begin{tabular}{llll}
\hline Bacteria/fungi & \multicolumn{2}{l}{ OD $^{\mathbf{6 2 0}}$; colony forming units (CFU)/mL } & Concentration III \\
\cline { 2 - 4 } & Concentration I & Concentration II & $1.49 ; 1.22 \times 10^{9}$ \\
\hline Escherichia coli & $0.54 ; 4.48 \times 10^{8}$ & $1.04 ; 8.56 \times 10^{8}$ & $1.51 ; 1.23 \times 10^{9}$ \\
Enterococcus faecium & $0.51 ; 4.02 \times 10^{8}$ & $1.06 ; 8.48 \times 10^{8}$ & $1.52 ; 1.25 \times 10^{9}$ \\
Lactobacillus rhamnosus & $0.56 ; 4.48 \times 10^{8}$ & $1.05 ; 8.72 \times 10^{8}$ & $1.50 ; 1.22 \times 10^{9}$ \\
Lactococcus lactis & $0.55 ; 4.40 \times 10^{8}$ & $1.06 ; 8.48 \times 10^{8}$ & $1.85 \times 10^{6}$ \\
Candida albicans & $1.75 \times 10^{4}$ & $2.85 \times 10^{5}$ & $1.8 \times 10^{6}$ \\
Candida glabrata & $1.55 \times 10^{4}$ & $2.7 \times 10^{5}$ & \\
\hline
\end{tabular}

by centrifugation and suspended in Jones' medium. The number of fungi cells was determined by counting in a Neubauer chamber (Heinz Herenz, Hamburg, Germany), and adjusted to the final concentrations (Table 1).

\section{Preparation of cell free supernatants (CFS)}

Cell free supernatant is a suspension of microorganism metabolites of chemical compounds. CFS of bacteria was obtained from TSB broth cultures after $21 \mathrm{~h}$ incubation at $37{ }^{\circ} \mathrm{C}$ by centrifugation at $4000 \times g$ for $10 \mathrm{~min}$. Supernatant was filtered through $0.20 \mu \mathrm{m}$ pore size filters (SARSTEDT AG \& Co. KG, Germany) [22]. The CFS of fungi was obtained from cultures on Sabouraud broth after 5 days of incubation at $24.5^{\circ} \mathrm{C}$ by centrifugation at $2300 \times g$ for $10 \mathrm{~min}$. The supernatant was sterilized by filtration with a $0.20 \mu \mathrm{m}$ syringe filter. The $\mathrm{pH}$ of all supernatants was measured.

\section{Metronidazole preparation}

A stock solution of metronidazole (MTZ, SigmaAldrich, USA), as a reference antiprotozoan drug [29] was prepared by adding $50 \mathrm{~mL}$ of sterile distilled water to $3000 \mathrm{mg}$ of the drug to give a final concentration of $60 \mathrm{mg} / \mathrm{mL}$. This was stored in a dark bottle at $4{ }^{\circ} \mathrm{C}$ [30]. MTZ was prepared at different concentrations directly before use in the experiment.

\section{Experimental setup and procedure}

The number of Blastocystis cells after 2 days of laboratory incubation used for the experiment was determined by counting in a Neubauer chamber. A final concentration of Blastocystis in Jones' medium was approximately $2.8 \times 10^{5}$ cells $/ \mathrm{mL}$ for the fungi experiment, $2.9 \times 10^{5}$ cells $/ \mathrm{mL}$ for the bacterial influence assay and $2.5 \times 10^{6} \mathrm{CFU} / \mathrm{mL}$ for the experiment using cell free supernatants. Sterile $5 \mathrm{~mL}$ polypropylene tubes (Equimed, Poland) were used. One milliliter of each microorganism described above and its CFSs were inserted into $5 \mathrm{~mL}$ tubes (Equimed) containing $3 \mathrm{~mL}$ of Jones' medium and $1 \mathrm{~mL}$ of Blastocystis xenic as well as axenic cultures in triplicate and the tubes were then sealed with a lid. Four milliliter of Jones medium with $1 \mathrm{~mL}$ of Blastocystis culture were used as control samples $(\mathrm{pH}=6.28)$ in the experiment containing alive microorganisms. For the CFS assay as control samples $1 \mathrm{~mL}$ of Blastocystis culture, $3 \mathrm{~mL}$ of Jones' medium and $1 \mathrm{~mL}$ of TSB $(\mathrm{pH}=6.25)$ or Sabouraud broth $(\mathrm{pH}=3.97)$ were used. The reference antiprotozoal drug metronidazole (MTZ) was tested against Blastocystis using three different concentrations $-1 \mu \mathrm{g} / \mathrm{mL}, 5 \mu \mathrm{g} / \mathrm{mL}$, and $10 \mu \mathrm{g} /$ $\mathrm{mL}$. The parasite was co-incubated for 5 days with each species of bacteria, and 7 days with each species of fungi because Candida sp. is a yeast which needs more time to multiply. Blastocystis was also co-incubated with supernatants of each microorganism for 6 days at $37{ }^{\circ} \mathrm{C}$ statically, in tightly closed polypropylene $5 \mathrm{~mL}$ tubes, in anaerobic conditions. Each day of incubation the number of Blastocystis cells was determined by counting in a Neubauer chamber. The viability of Blastocystis cells was assessed by using staining with $0.4 \%$ Trypan blue solution. Unstained cells were counted. The $\mathrm{pH}$ was measured every day of co-incubation. All experiments were repeated three times.

The influence on Blastocystis was determined by calculating the mean and SD (standard deviation) of the number of parasite cells in the $5 \mathrm{~mL}$ tubes with microorganisms and the mean of number of Blastocystis cells in the control samples. A cell count was taken for each bacterial and fungal concentration as well as for cell free supernatants. The results were reported as an average.

\section{Statistical analysis}

The number of viable morphological forms of Blastocystis in treatment and controls were compared using $t$-test (GraphPad Prism 7.04), as well as Pearson Chi square and two-way ANOVA tests were used whenever appropriate. To compare the influence of the dilutions according to the time of co-incubation, three-way ANOVA (Tukey's test) was used. A $p$ value of $<0.05$ was considered as statistically significant. 


\section{Results}

\section{Co-incubation of bacteria with Blastocystis ST3 xenic culture}

The antiparasitic activity of the chosen bacteria against Blastocystis ST3 was investigated in vitro. The results of this study showed that the bacterial inoculum had an influence with regards to the protozoan, but the effectiveness of some of them is more intense than the others. The mean and standard deviation values were calculated with respect to the cell counts of the control. In control samples, Blastocystis proliferation was observed from 2 to 5 days. The total viable Blastocystis cells in bacteriatreated cultures were counted every day starting from the 2nd day of co-incubation when the number of parasites increased significantly after the addition of different concentrations of E. coli and E. faecium (Fig. 1). An inhibition of Blastocystis division was observed after 3 days and later of co-incubation with L. rhamnosus and L. lactis (Fig. 1). In this case, the number of Blastocystis cells co-incubated with E. coli and E. faecium was similar to the control samples. Furthermore, after 4 and 5 days $E$. faecium and E. coli had a negative influence on Blastocystis proliferation, and that inhibition was statistically significant.

The influence of different bacterial concentrations was statistically analyzed. The number of added E. coli cells when the optical density $\left(\mathrm{OD}^{620}\right)$ was 0.5 and $1.5\left(4.48 \times 10^{8} \mathrm{CFU} / \mathrm{mL}\right.$ and $1.22 \times 10^{9} \mathrm{CFU} / \mathrm{mL}$, respectively) had a significant influence on increased Blastocystis proliferation during the first 2 days $(\mathrm{p}=0.0007$ and $\mathrm{p}=0.0301)$ as compared to the control sample. As mentioned above, the number of parasites decreased on the 5th day of co-incubation with E. coli. In this case, the concentration $\mathrm{OD}^{620}=0.5$ again had a significant influence $(\mathrm{p}=0.023)$. The $\mathrm{OD}^{620}=1.0$ concentration also inhibited protozoan proliferation $(p=0.0474)$. Similar results were observed with regards to E. faecium. After the first 2 days, a higher number of Blastocystis cells co-incubated with the $\mathrm{OD}^{620}=1.0\left(8.48 \times 10^{8} \mathrm{CFU} /\right.$ $\mathrm{mL})$ concentration of $E$. faecium was noted $(\mathrm{p}=0.0021)$, and during the 5 th day the $\mathrm{OD}^{620}=1.5\left(1.23 \times 10^{9} \mathrm{CFU} /\right.$ $\mathrm{mL}$ ) concentration inhibited the proliferation of the protozoan cells $(\mathrm{p}=0.0063)$.

Of the four tested bacteria, L. rhamnosus and L. lactis definitely inhibited Blastocystis growth from the 2nd day of co-incubation, as compared to the control samples. Inhibition was perfectly visible during all 5 days when $\mathrm{OD}^{620}=1.0$ concentration $\left(8.72 \times 10^{8} \mathrm{CFU} / \mathrm{mL}\right.$ and $8.48 \times 10^{8} \mathrm{CFU} / \mathrm{mL}$, respectively) was added and this was statistically significant $(\mathrm{p}=0.0076$ and $\mathrm{p}=0.0383)$.

\section{Co-incubation of bacteria with Blastocystis ST3 axenic culture}

In control samples, Blastocystis proliferation was observed from 2 to 5 days, but according to the xenic culture the number of protozoan cells was lower. Total
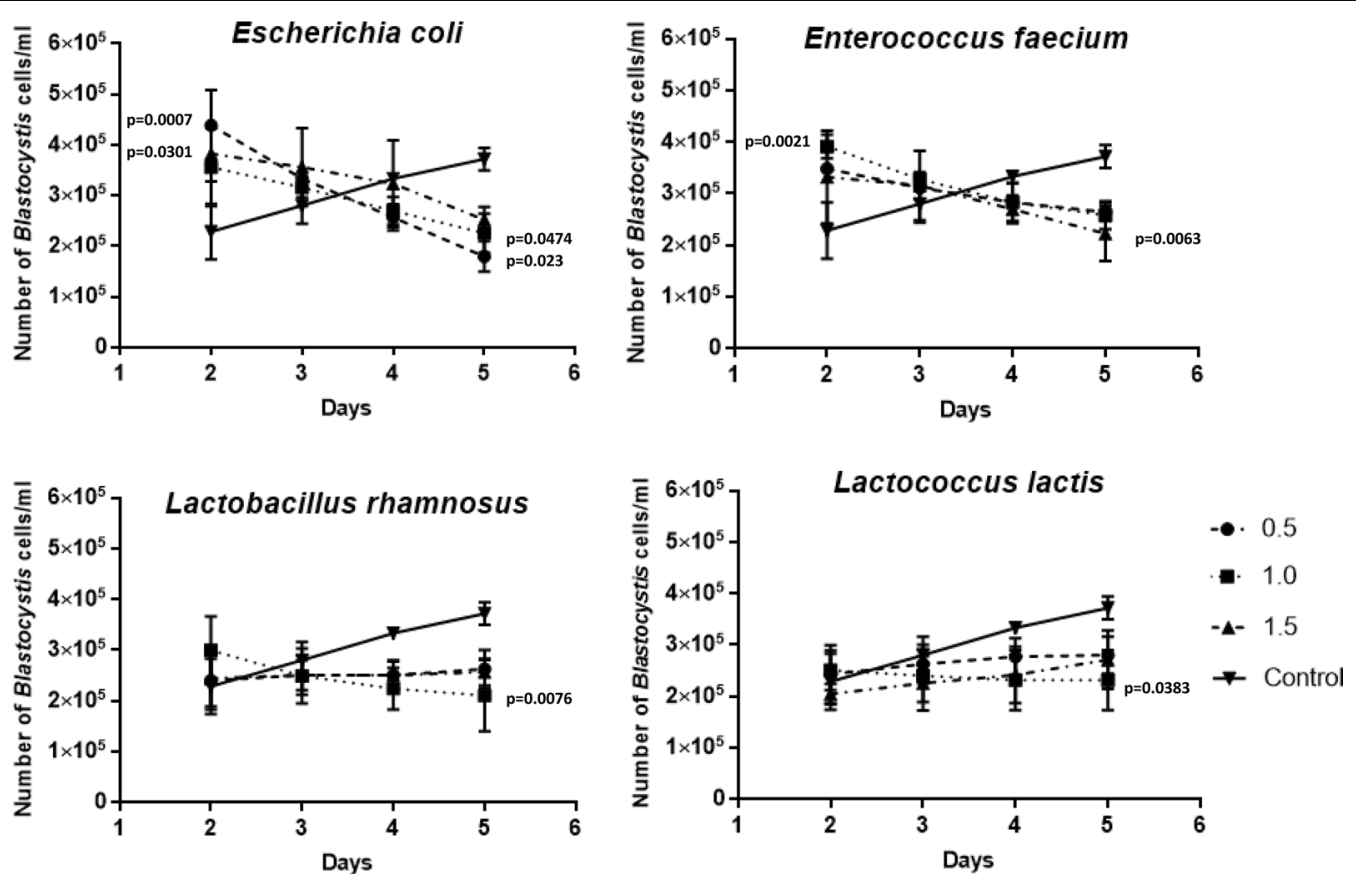

Fig. 1 The influence of different concentrations $\mathrm{OD}^{620}=0.5,1.0$ and 1.5 of chosen bacteria on Blastocystis xenic culture development according to time of co-incubation 
viable Blastocystis cells in bacteria-treated cultures were counted every day starting from the 2nd day of co-incubation when the number of parasites increased significantly after the addition of different concentrations of $E$. coli (Fig. 2). E. faecium did not influence the Blastocystis significantly. A decrease in Blastocystis cell viability was observed after 3 days and later after co-incubation with L. rhamnosus and L. lactis (Fig. 2). Furthermore, in this case the number of Blastocystis cells co-incubated with E. coli and E. faecium was similar to the control samples. Also, after four and 5 days $E$. coli had a negative influence on Blastocystis proliferation, and that inhibition was statistically significant.

The influence of different bacterial concentrations was statistically analyzed. The number of added E. coli cells when optical density $\left(\mathrm{OD}^{620}\right)$ was $0.5,1.0$ and $1.5\left(4.48 \times 10^{8} \mathrm{CFU} / \mathrm{mL}, 8.56 \times 10^{8} \mathrm{CFU} / \mathrm{mL}\right.$, and $1.22 \times 10^{9} \mathrm{CFU} / \mathrm{mL}$, respectively) significantly influenced a higher Blastocystis proliferation after the first 2 days $(\mathrm{p}<0.0001)$ as compared to the control sample. The number of parasites decreased on the 5th day of co-incubation with E. coli. In this case, all of the different concentrations $\left(\mathrm{OD}^{620}=0.5,1.0\right.$, and 1.5$)$ again had a statistically significant influence $(\mathrm{p}<0.0001, \mathrm{p}=0.0003, \mathrm{p}<0.0001$, respectively). A similar situation with regards to $E$. faecium was observed. After the first 2 days, a higher number of Blastocystis cells co-incubated with the $\mathrm{OD}^{620}=0.5$ and
$\mathrm{OD}^{620}=1.0\left(4.02 \times 10^{8} \mathrm{CFU} / \mathrm{mL}, 8.48 \times 10^{8} \mathrm{CFU} / \mathrm{mL}\right)$ concentration of E. faecium was noted. Moreover, during the 5th day the number of Blastocystis cells decreased but not significantly (Fig. 2).

In the experiment with L. rhamnosus and L. lactis the inhibition of Blastocystis proliferation was noted during the entire duration of the co-incubation. This was quite clearly visible during the 3rd day of co-incubation when $\mathrm{OD}^{620}=0.5$ and $\mathrm{OD}^{620}=1.0$ concentrations of $L$. rhamnosus $\left(4.48 \times 10^{8} \mathrm{CFU} / \mathrm{mL}\right.$ and $8.72 \times 10^{8} \mathrm{CFU} / \mathrm{mL}$, respectively) were added. Statistical analysis showed significance with $p$-values lower than $0.05, \mathrm{p}=0.0337$ and $\mathrm{p}=0.0269$, respectively. On the 5 th day, all of the concentrations of L. rhamnosus and L. lactis significantly inhibited Blastocystis growth.

Both experiments, with xenic and axenic cultures, showed similar results with regards to Blastocystis inhibition by $L$. rhamnosus and $L$. lactis from the 2nd day of co-incubation with those bacteria. Also in both, co-incubation with E. faecium and E. coli showed a beneficial influence on Blastocystis during first 2 days. Only after 3 days did the above-mentioned bacteria start to inhibit Blastocystis growth in xenic and axenic culture. Usually the vacuolar form was observed. The cyst form occurred rare. In the cultures co-incubated with E. coli and E. faecium a high level of amoebic forms of Blastocystis was noticed.
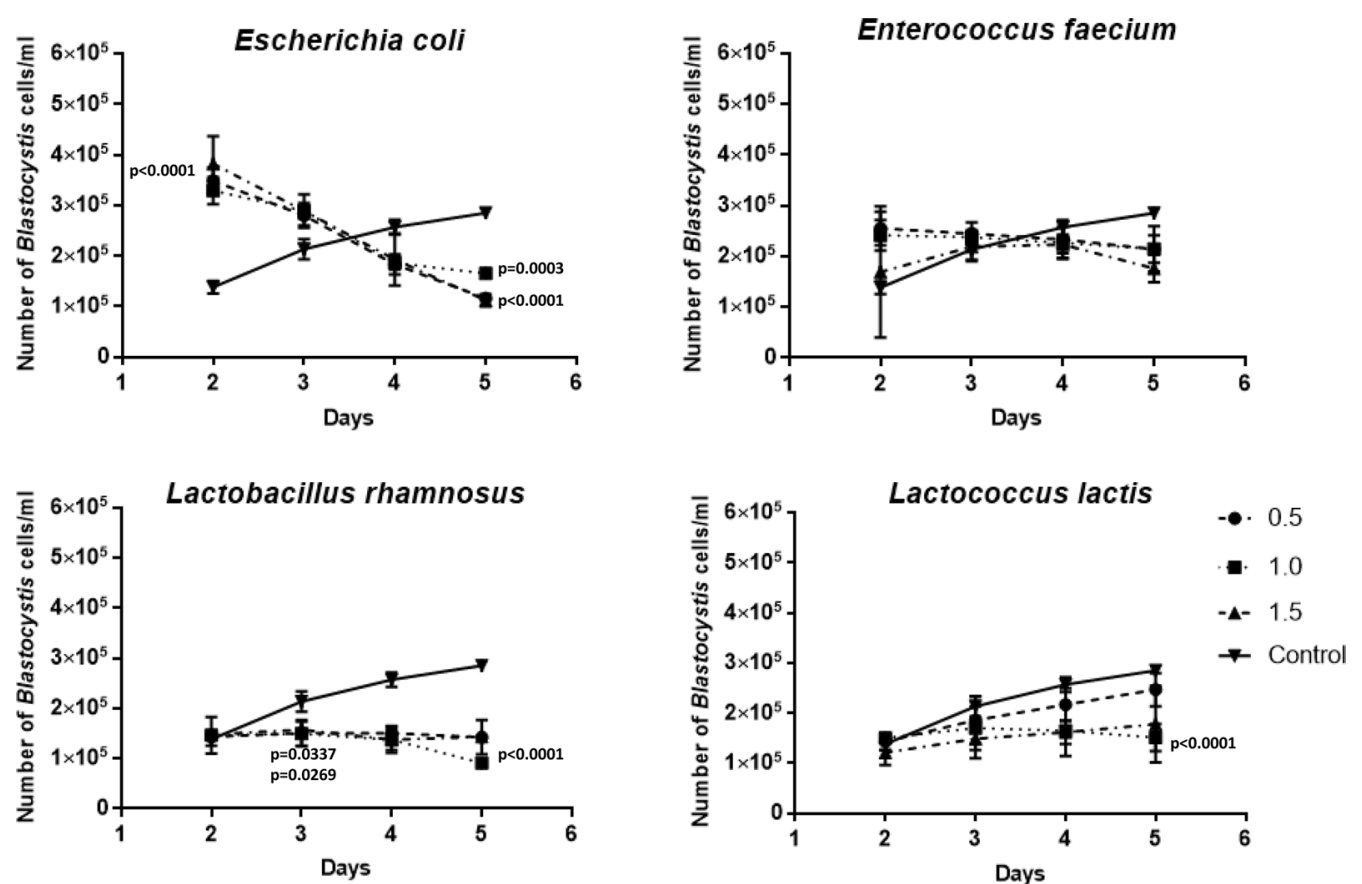

Fig. 2 The influence of different concentrations $\mathrm{OD}^{620}=0.5,1.0$ and 1.5 of chosen bacteria on Blastocystis axenic culture development according to time of co-incubation 


\section{Co-incubation of fungi with Blastocystis ST3 xenic and axenic culture}

Both Candida albicans and Candida glabrata showed only a modest decrease of $30 \%$ cell loss compared to the bacteria. The results of this study showed that the fungal suspension had an influence on Blastocystis, but the effectiveness was lower than that of bacteria (Fig. 3). The mean and standard deviation values were calculated with respect to the cell counts of the control. In control samples, Blastocystis proliferation was observed from 2 to 4 days. After that time it began to decrease. Total viable Blastocystis cells in fungi-treated cultures were counted every day starting from 2 days of co-incubation when the number of the parasite increased after the addition of $10^{5} \mathrm{CFU} / \mathrm{mL}$ and $10^{6} \mathrm{CFU} / \mathrm{mL}$ concentrations of Candida albicans in both xenic and axenic culture (Fig. 3a, c). During the 4th day, in both control and co-incubated samples, the number of Blastocystis cells started to slowly decrease. Compared to the control samples, co-incubation with both Candida albicans and Candida glabrata showed a faster decrease in Blastocystis proliferation (Fig. 3a, b). This was not statistically significant. A similar situation was noticed in the axenic culture experiment (Fig. 3c, d). Usually the vacuolar form occurred in the co-incubated samples. Interestingly, the amoeboid form was observed quite often as well as granular and cyst form.

\section{Co-incubation of cell free supernatant}

Only bacterial supernatants of E. faecium, L. rhamnosus and L. lactis inhibited Blastocystis proliferation in xenic culture significantly $(\mathrm{p}<0.0001)$ from the 2 nd day of co-incubation (Fig. 4a). The supernatant containing the metabolites of $E$. coli was effective to a lower degree. Also, in axenic culture three supernatants obtained from E. faecium, L. rhamnosus and L. lactis had a negative influence on Blastocystis development, but mostly it was L. rhamnosus and L. lactis ( $p$-values between 0.0055 and $<0.0001$ ) (Fig. 4b). The CFS obtained from E. coli had no influence on the axenic culture of Blastocystis. The fungal supernatants seemed not to exhibit any inhibition on Blastocystis growth in xenic and axenic cultures (Fig. 5a). Moreover, it showed a higher number of Blastocystis cells in xenic cultures (Fig. 5b) with the addition of supernatants than in control samples. Most probably the reason is a lower $\mathrm{pH}$ of microbiological medium in control samples.

\section{$\mathrm{pH}$ changes during co-incubation}

The $\mathrm{pH}$ of all of the co-cultures was measured as well as cell free supernatants and microorganisms cultures on appropriate media. The $\mathrm{pH}$ of CFS of $E$. coli was equal to 6.5, E. faecium-5.45, L. rhamnosus-5.0, L. lactis-5.26, C. albicans-4.53 and C. glabrata-4.71. The $\mathrm{pH}$ of E. coli culture incubated for 2 days on TSB was equal to 6.1, $E$.
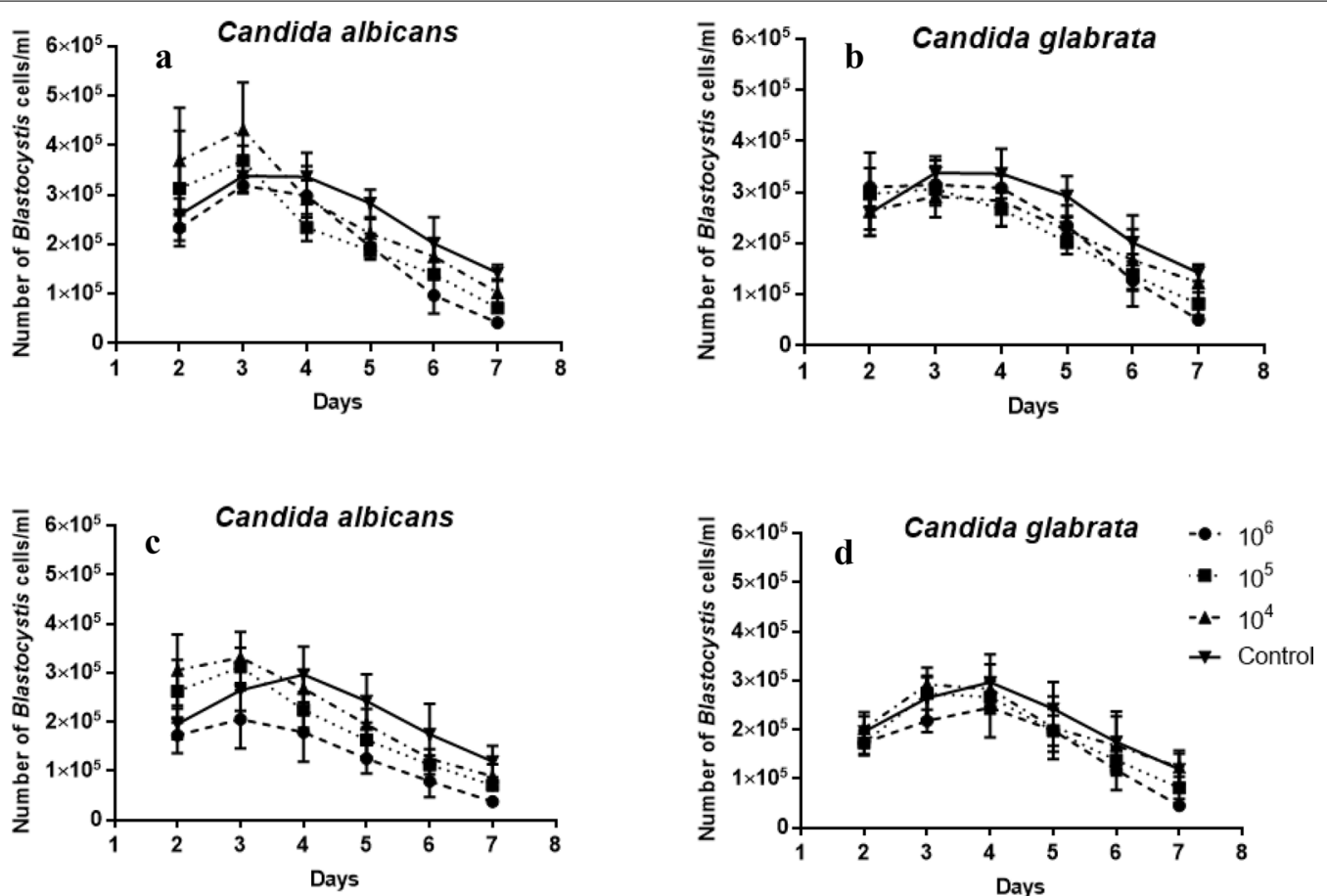

Fig. 3 The influence of different concentrations of chosen fungi on Blastocystis xenic $(\mathbf{a}, \mathbf{b})$ and axenic $(\mathbf{c}, \mathbf{d})$ culture development according to time of co-incubation 


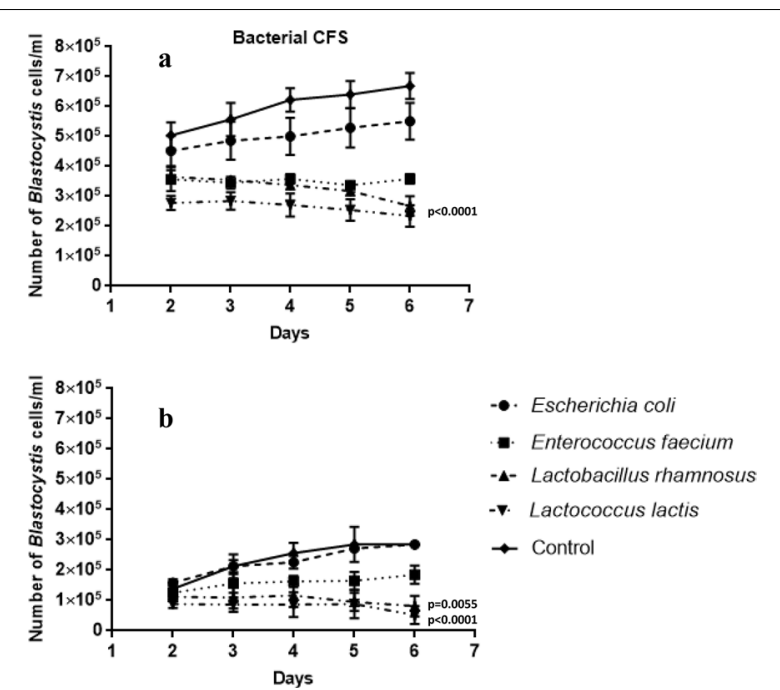

Fig. 4 The influence of bacterial cell free supernatants (CFS) on Blastocystis xenic (a) and axenic (b) culture development according to time of co-incubation

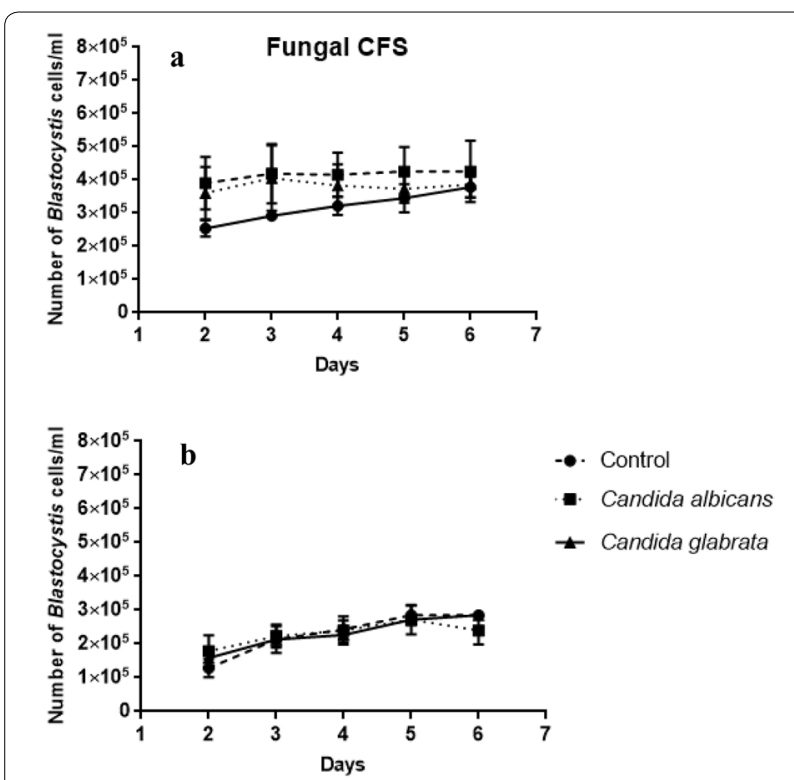

Fig. 5 The influence of fungal cell free supernatants (CFS) on Blastocystis xenic (a) and axenic (b) culture development according to time of co-incubation

faecium-5.36, L. rhamnosus-4.94, L. lactis-5.16, and of C. albicans culture incubated for 6 days on Sabouraud broth was equal to 4.65, C. glabrata-4.68.

The $\mathrm{pH}$ of Blastocystis cultures co-incubated with alive bacteria (Fig. 6a) ranging from 6.26 at the 1st day to 6.48 at the 5th day of co-incubation and alive fungi (Fig. 7a) ranging from 6.29 at the 1 st day to 6.59 at the 7 th day of co-incubation was higher regarding to the control samples ( $\mathrm{pH}$ value from 6.28 to 6.44 at the 5th day and 6.54 at the 7th day). Also the $\mathrm{pH}$ of Blastocystis cultures coincubated with fungal CFSs (Fig. 7b)-from 5.78 to 6.5 at the 7th day was higher regarding to the control samples (from 3.97 to 3.88 at the 7th day). Conversely, the $\mathrm{pH}$ of Blastocystis cultures co-incubated with bacterial CFSs ranging from 6.25 at the 1 st day to 6.49 at the 5 th day of co-incubation was lower than in control samples-from 6.25 to 6.75 (Fig. 6b).

It can be assumed that the small $\mathrm{pH}$ differences did not influence on Blastocystis proliferation significantly.

\section{Metronidazole control}

Living lactic acid bacteria, L. rhamnosus and L. lactis, as well as their cell free supernatants had a similar effect to the MTZ control concentrations of $10 \mu \mathrm{g} / \mathrm{mL}$ and $5 \mu \mathrm{g} /$ $\mathrm{mL}$ in xenic cultures of Blastocystis. Axenic culture could not be described, because of a low number of Blastocystis cells which nearly all died after the addition of different concentrations of MTZ. With regards to this, there were statistically significant differences between both $E$. coli and E. faecium, as well as C. albicans, C. glabrata and MTZ addition ( $\mathrm{p}<0.0001)$.

\section{Discussion}

Natural gut microbiota plays a very important role in controlling intestinal diseases and keeping the intestines healthy. Studies have shown that intestinal microbiota could alter the Blastocystis [16]. Consequently, suggestions have been made that the use of the antiprotozoal drug known as metronidazole could give rise to drug resistant Blastocystis subtypes [31]. Moreover, metronidazole, which is the first-line treatment, has been shown to exhibit side effects and quite often a low effectiveness of this drug during eradication is noted [32]. As an alternative, we have tried to explore the potential of probiotic bacteria. We studied the response of Blastocystis in vitro to two different strains of the Lactobacillaceae family- $L$. rhamnosus and L. lactis, as well as E. faecium. In addition, we tried to define the role of $E$. coli and two fungal strains from the Candidaceae family in protozoan development using concentrations similar to that in a healthy human colon.

Our study shows the strong inhibitory effect of various lactic acid bacteria (LAB) at different concentrations on the proliferation of the Blastocystis from the beginning of co-incubation in xenic and axenic culture, whereas E. faecium and E. coli exhibited anti-proliferative activity after 4 days. In the case of co-incubation with E. faecium and E. coli, a high level of amoebic forms of Blastocystis was noticed. It may mean that the bacteria mentioned above are beneficial for Blastocystis 

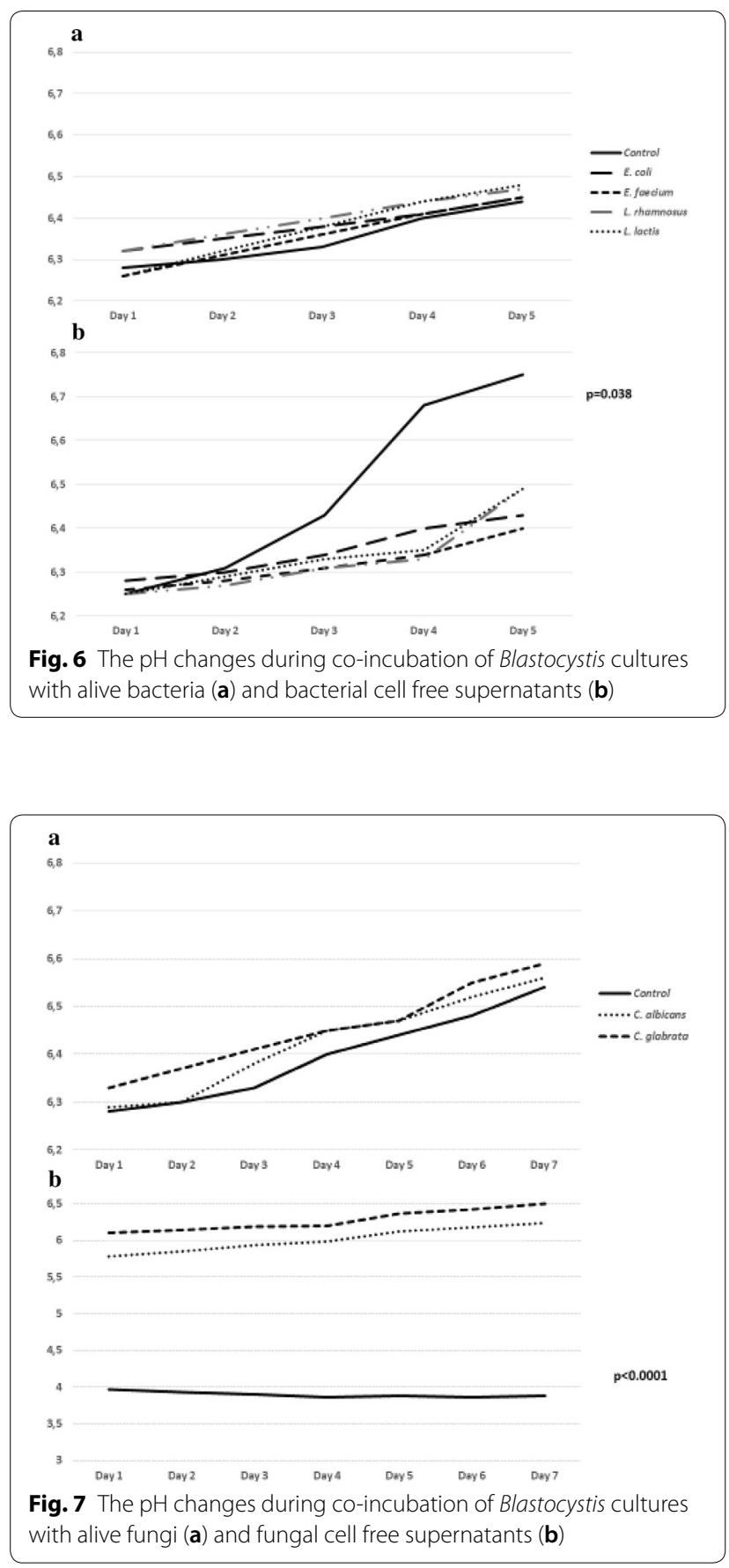

development and confirms the previous research of Rajamanikam and Govind [33], who suggest that the amoebic form is found during optimal conditions for Blastocystis growth and plays a role in the exacerbation of intestinal symptoms during Blastocystis colonization. In our study, fungi from the Candidaceae family had little antiprotozoal influence, as well as forcing the vacuolar forms into cysts and granular forms. Those forms are usually observed during thermal stress, as Thergarajan et al. [34] reported in their research.

Our experiments on axenic cultures of the parasite confirmed a strong negative influence of LAB on Blastocystis. The cell free supernatants of bacteria were used for further investigation to determine whether the bacterial metabolites showed similar results. Sarjapuram et al. [22] reported the inhibition of other protozoan proliferation by spent media of probiotic culture. They noticed changes of the $\mathrm{pH}$ of microbiological media and adjusted it to eliminate its influence on Entamoeba growth [22]. Similarly, our study showed that not only living bacteria had a negative influence on Blastocystis, but also their metabolites. Zhang et al. [35] determined the optimal pH for Blastocystis growth to be 7.0 [35].

Our study clearly shows the inhibition of Blastocystis proliferation by LAB, which suggests that people using probiotic rich diets and having a stable gut microbiota are more resistant to protozoan colonization. Several previous studies revealed that the total bacterial population, as well as bacterial groups such as Bifidobacterium sp., Bacteroides spp., and Clostridium sp., shows a high degree of temporal stability [36-39]. However, the situation is different for the Lactobacillus population. The Walter et al., Vanhoutte et al., and Scanlan et al. studies of fecal samples from most human subjects showed temporal dynamics that were characterized by fluctuations and a lack of stability [36, 38, 40]. A lack of these bacteria in the large intestine caused by a poor diet, antibiotic therapy or taking drugs for gastrointestinal disorders such as proton pomp inhibitors (PPI) may influence the susceptibility to Blastocystis invasions $[41,42]$. The interesting thing is that all of the bacterial concentrations used in this study affected the parasite proliferation. This suggests that lower bacterial CFUs may also be used for Blastocystis eradication. Molan in his research [18] suggested, which we validated in our work, that the factor which causes that inhibition may be the bacteria themselves or their chemical compounds. Lactobacilli increase their protective or therapeutic effect through the production of antimicrobial compounds [43], a reduction of gut $\mathrm{pH}$ by stimulating the lactic acid producing microflora [44], competition for binding of receptor sites that pathogens occupy and competition with pathogens for available nutrients $[45,46]$. Nisin-producing $L$. lactis strains have high antimicrobial properties [47]. This study shows that lactic acid produced by the Lactobacillaceae family lowered the $\mathrm{pH}$ of the TSB medium, but not of the Jones' medium during co-incubation with Blastocystis. That means the $\mathrm{pH}$ could not be a reason for the decline of Blastocystis, as has been reported about other protozoan parasites such as Entamoeba histolytica, Giardia sp. or Eimeria sp. [19, 21, 22, 48]. 
The other situation has been demonstrated by $E$. faecium and E. coli. Some strains of the first of these bacteria has been reported to be an effective probiotic species [22]. Our study confirmed the data from the Sarjapuram [22] research. The authors reported that E. faecium inhibited Eimeria after $24 \mathrm{~h}$ of co-incubation with a total bacterial CFU of $10^{8}$ cells $/ \mathrm{mL}$. Blastocystis ST3 seems to be more resistant to its influence. In our experiment, the more effective concentration was $1.23 \times 10^{9} \mathrm{CFU} / \mathrm{mL}$, as well as a longer incubation time -4 or 5 days. Most likely, it lasts longer because E. faecium produces strong antimicrobial, yet no antiprotozoal compounds, and it does not compete for enteric adherence sites. More likely, this is caused by competing for nutrients. This could be due to it being a lactic acid bacteria which colonizes differently, and competes with Blastocystis differently [49].

In human medicine, E. faecium has been used successfully in the treatment of acute diarrheal diseases and in the prevention of antibiotic-associated diarrhea [50,51]. Starke et al., as well as Klingspor et al. in 2015, investigated the intestinal microbiota of pigs whose components are similar to human gut microorganisms [52, 53]. They showed that the probiotic bacteria E. faecium modifies the porcine intestinal microbiota and modulates epithelial integrity, heat shock protein as well as the proinflammatory cytokine response in intestinal cells. That could lead to the eradication of intestinal pathogens, including protozoans. Our study showed the dependence of Blastocystis on a fecal bacteria presence. In axenic control cultures, there were far fewer Blastocystis cells than in xenic culture, which means the intestinal commensal bacteria have a role in parasite development. One possible explanation for Blastocystis eradication by E. faecium may be the direct growth inhibiting effect of the probiotic on other intestinal bacteria, such as E. coli, Clostridium sp. or other fecal commensal microorganisms. Bednorz et al. [54] showed in their data a minor influence of E. faecium on the overall population of non-pathogenic $E$. coli in healthy piglets. However, this same strain has a profound effect on mucosa-adherent $E$. coli. Russo et al. and Kaper et al. reported that $E$. faecium 10415 significantly reduced pathogenic organisms, such as extraintestinal E. coli (ExPEC) [55, 56]. To sum up, there may be two ways of Blastocystis eradication by E. faecium: directly by cellular compounds and nutrient competition, and indirectly by killing the beneficial intestinal bacteria.

The results of our E. coli experiment were quite interesting. The number of Blastocystis cells increased, then after the 4th day began to decrease significantly. In the Ganas et al. study from 2012, E. coli was found to strongly support the growth of the parasite-Histomonas meleagridis, which may suggest it is a beneficial bacteria for protozoan parasite development [57]. That may be an explanation for the increase of Blastocystis proliferation, especially if $E$. coli is also an intestinal microorganism. The question remains as to why the number of Blastocystis cells decreased significantly after 5 days of co-incubation? One option may be the fact that the bacteria might be absorbed by Blastocystis at first while only low numbers of $E$. coli cells were in the incubated tubes. That supports protozoan proliferation. Another option is that $E$. coli produces endotoxins, such as lipopolysaccharides (LPS) which could negatively influence Blastocystis cells from inside after phagocytosis which was observed in amoebic form and destroy the parasite [57-59].

There are not many studies regarding the influence of Candida on protozoans. Mostly the researchers have focused on interactions between intestinal fungi and bacteria [60]. Our study focused on the interaction between Blastocystis and Candida albicans and Candida glabrata to determine if people who are colonized by that fungi as the natural microbiota of the human intestine are more susceptible or resistant to Blastocystis invasions. It can therefore be assumed that both Candida should to a small degree inhibit the potential pathogenic protozoan development in the intestine just as other yeasts like Saccharomyces boulardii [24]. Our study shows almost no inhibitory effect on Blastocystis by C. glabrata and only limited inhibition by C. albicans in $10^{6}$ cells $/ \mathrm{mL}$ concentration. Moyes et al. [61] reported that Candida does not produce any toxins influencing protozoa, but produces some toxins against bacteria and epithelial cells. Also, these do not change the $\mathrm{pH}$ of the environment. Moreover, Konno et al. and Sherrington et al. proved Candida adapt to environmental $\mathrm{pH}$ changes [62,63]. A minor decrease in the number of Blastocystis cells was most likely caused by competition between the protozoan and Candida for space and nutrition [64].

Our study has shown the potential of using $L$. rhamnosus and L. lactis, as well as E. faecium as probiotics against Blastocystis colonization. The fact that these probiotic bacterial strains are able to disrupt the cell cycle of Blastocystis shows a promising future in the use of probiotics for prophylactic treatment of blastocystosis, or as an additional treatment regimen in combination with standard drugs. The obtained results did not show what is the mechanism of Blastocystis inhibition by lactic acid bacteria. This issue requires further research.

\footnotetext{
Authors' contributions

ML was responsible for idea conception, designed and performed the experiment, analysed the data and drafted and wrote this manuscript; ED was responsible for critical evaluation and manuscript review. All authors read and approved the final manuscript.
}

Acknowledgements Not applicable. 


\section{Competing interests}

The authors declare that they have no competing interests.

\section{Availability of data and materials}

The dataset supporting the conclusion of this article are included within the article.

\section{Consent for publication}

Not applicable.

\section{Ethics approval and consent to participate}

Not applicable.

\section{Funding}

Not applicable.

\section{Publisher's Note}

Springer Nature remains neutral with regard to jurisdictional claims in published maps and institutional affiliations.

Received: 29 August 2018 Accepted: 5 February 2019

Published online: 14 February 2019

\section{References}

1. Tan KS. New insights on classification, identification and clinical relevance of Blastocystis spp. Clin Microbiol Rev. 2008;21(4):639-65.

2. Scanlan PD, Stensvold CR, Rajilić-Stojanović M, Heilig HG, De Vos WM, O'Toole PW, Cotter PD. The microbial eukaryote Blastocystis is a prevalent and diverse member of the healthy human gut microbiota. FEMS Microbiol Ecol. 2014;90(1):326-30

3. Basak S, Rajurkar MN, Mallick SK. Detection of Blastocystis hominis: a controversial human pathogen. Parasitol Res. 2014;113(1):261-5.

4. Lukes J, Stensvold CR, Jirků-Pomajbíková K, Parfrey LW. Are human intestinal eukaryotes beneficial or commensals? PLoS Pathog. 2015;11(8):e1005039.

5. Noël C, Dufernez F, Gerbod D, Edgcomb VP, Delgado-Viscogliosi P, Ho LC, Singh M, Wintjens R, Sogin ML, Capron M, Pierce R, Zenner L, Viscogliosi E. Molecular phylogenies of Blastocystis isolates from different hosts: implications for genetic diversity, identification of species and zoonosis. J Clin Microbiol. 2005:43(1):348-55.

6. El Safadi D, Gaayeb L, Meloni D, Cian A, Poirier P, Wawrzyniak I, Delbak F, Dabboussi F, Delhaes L, Seck M, Hamze M, Riveau G, Viscogliosi E. Children of Senegal River Basin show the highest prevalence of Blastocystis sp. ever observed worldwide. BMC Infect Dis. 2014;14:164-74.

7. Albrecht H, Stellbrink HJ, Koperski K, Greten H. Blastocystis hominis in human immunodeficiency virus — related diarrhea. Scand J Gastroenterol. 1995;30(9):909-14.

8. Sanchez-Aguillon F, Lopez-Escamilla E, Velez-Perez F, Martinez-Flores WA, Rodriguez-Zulueta P, Martinez-Ocaña J, Martinez-Hernandez F, RomeroValdovinos M, Maravilla P. Parasitic infections in a Mexican HIV/AIDS cohort. J Infect Dev Ctries. 2013;7(10):763-6.

9. Lu CTL, Sung YJ. Epidemiology of Blastocystis hominis and other intestinal parasites among the immigrant population in northeastern by routine physical examination for resistance approval. J Microbiol Immunol Infect. 2009:42(6):505-9.

10. Zaglool DAM, Khodari YAW, Farooq MU. Blastocystis hominis and allergic skin diseases; a single centre experience. J H Sci. 2012;2(1):66-9.

11. Abdel-Hameed DM, Hassanin OM. Protease activity of Blastocystis hominis subtype 3 in symptomatic and asymptomatic patients. Parasitol Res. 2011;109(2):321-7.

12. Teow WL, Ho LC, Ng GC, Chan YC, Yap EH, Chan PP, Howe J, Zaman V, Singh M. Virus - like particles in a Blastocystis species from the sea snake Lapemi hardwickii. Int J Parasitol. 1992;22(7):1029-32.

13. Berrilli F, Di Cave D, Cavallero S, D'Amelio S. Interactions between parasites and microbial communities in the human gut. Front Cell Infect Microbiol. 2012:2:141

14. Nourrisson C, Wawrzyniak I, Cian A, Livrelli V, Viscogliosi E, Delbac F, Poirier P. On Blastocystis secreted cysteine proteases: a legumain-activated cathepsin B increases paracellular permeability of intestinal Caco-2 cell monolayers. Parasitology. 2016;146(13):1713-22.

15. Nagel R, Traub RJ, Allcock RJN, Kwan MMS, Bielefeldt-Ohmann H. Comparison of faecal microbiota in Blastocystis-positive and Blastocystisnegative irritable bowel syndrome patients. Microbiome. 2016;4(1):47.

16. Audebert C, Even G, Cian A, The Blastocystis Investigation Group, Loywick A, Merlin S, Viscogliosi E, Chabé M. Colonization with the enteric protozoa Blastocystis is associated with increased diversity of human gut bacterial microbiota. Nat Sci Rep. 2016; Article number 25255. https://doi. org/10.1038/srep25255

17. lebba V, Santangelo F, Totino V, Pantanella F, Monsia A, Di Cristanziano V, Di Cave D, Schippa S, Berrilli F, D'Alfonso R. Gut microbiota related to Giardia duodenalis, Entamoeba spp. and Blastocystis hominis infections in humans from Côte d'Ivoire. J Infect Dev Ctries. 2016;10(9):1035-41.

18. Molan AL. Bacteria versus parasites: effect of Lactobacillu rhamnosus cell-free supernatant on the sporulation of coccidian oocysts in vitro and in vivo. IOSR J Dental Med Sci. 2014;13(6):86-92.

19. Goyal N, Tiwari RP, Shukla G. Lactobacillus rhamnosus GG as an effective probiotic for murine giardiasis. Interdiscip Perspect Infect Dis. 2011;2011:795219.

20. Pérez PF, Minnaard J, Rouvet M, Knabenhans C, Brassart D, De Antoni GL, Schiffrin EJ. Inhibition of Giardia intestinalis by extracellular factors from Lactobacilli: an in vitro study. Appl Environ Microbiol. 2011:67(11):5037-42.

21. Tierney J, Gowing H, Van Sinderen D, Flynn S, Stanley L, McHardy N, Hallahan S, Mulcahy G. In vitro inhibition of Eimeria tenella invasion by indigenous chicken Lactobacillus species. Vet Parasitology. 2004;122(3):171-82.

22. Sarjapuram N, Mekala N, Singh M, Tatu U. The potential of Lactobacillus casei and Enterococcus faecium combination as a preventive probiotic against Entamoeba. Probiotics Antimicrob Proteins. 2016;9(2):142-9.

23. Simpson KW, Rishniw M, Bellosa M, Liotta J, Lucio A, Baumgart M, Czarnecki-Maulden G, Benyacoub J, Bowman D. Influence of Enterococcus faecium SF68 probiotic on giardiasis in dogs. J Vet Intern Med. 2009;23(3):476-81.

24. Dinleyici EC, Eren M, Dogan N, Reyhanioglu S, Yargic ZA, Vandenplas Y. Clinical efficacy of Saccharomyces boulardii or metronidazole in symptomatic children with Blastocystis hominis infection. Parasitol Res. 2011;108(3):541-5.

25. Hill C, Guarner F, Reid G, Gibson GR, Merenstein DJ, Pot B, Morelli L, Canani RB, Flint HJ, Salminen S, Calder PC, Sanders ME. Expert consensus document. The International Scientific Association for Probiotics and Prebiotics consensus statement on the scope and appropriate use of the term probiotic. Nat Rev Gastroenterol Hepatol. 2014;11 (8):506-14.

26. Jones WR. The experimental infection of rats with Entamoeba histolytica; with a method for evaluating the anti-amoebic properties of new compounds. Ann Trop Med Parasitol. 1946:40:130-40.

27. Leelayoova S, Taamasri P, Rangsin R, Naaglor T, Thathaisong U, Mungthin M. In-vitro cultivation: a sensitive method for detecting Blastocystis hominis. Ann Trop Med Parasitol. 2002:96(8):803-7.

28. El Deeb HK, Al Khadrawy FM, Abd El-Hameid A. Inhibitory effect of Ferula asafetida L. (Umbelliferae) on Blastocystis sp. subtype 3 growth in vitro. Parasitol Res. 2012;111(3):1213-21.

29. Sawangjaroen N, Sawangjaroen $K$. The effects of extracts from anti-diarrheic Thai medicinal plants on the in vitro growth of the intestinal protozoa parasite: blastocystis hominis. J Ethnopharmacol. 2005;98(1-2):67-72.

30. Haresh K, Suresh K, Khairul Anus A, Saminathan S. Isolate resistance of Blastocystis hominis to metronidazole. Trop Med Int Health. 1999:4(4):274-7.

31. Dunn LA, Tan KS, Vanelle P, Juspin T, Crozet MD, Terme T, Upcroft P, Upcroft JA. Development of metronidazole-resistant lines of Blastocystis sp. Parasitol Res. 2012;111(1):441-50.

32. Batista L, Pérez Jove J, Rosinach M, Gonzalo V , Sainz E, Loras C, Forné M, Esteve M, Fernández-Bañares F. Low efficacy of metronidazole in the eradication of Blastocystis hominis in symptomatic patients: case series and systematic literature review. Gastroenterol Hepatol. 2017;40(6):381-7.

33. Rajamanikam A, Govind SK. Amoebic forms of Blastocystis spp.-_evidence for a pathogenic role. Parasites Vectors. 2013;6(1):295.

34. Thergarajan G, Govind SK, Bhassu S. In vitro and in vivo thermal stress induces proliferation of Blastocystis sp. Parasitol Res. 2018;117(1):177-87. 
35. Zhang X, Qiao J, Wu X, Da R, Zhao L, Wei Z. In vitro culture of Blastocystis hominis in three liquid media and its usefulness in the diagnosis of blastocystosis. Int J Infect Dis. 2012;16(1):e23-8.

36. Scanlan PD, Shanahan F, O'Mahony C, Marchesi JR. Culture-independent analyses of temporal variation of the dominant fecal microbiota and targeted bacterial subgroups in Crohn's disease. J Clin Microbiol. 2006;44(11):3980-8.

37. Tannock GW, Munro K, Harmsen HJ, Welling GW, Smart J, Gopal PK. Analysis of the fecal microflora of human subjects consuming a probiotic product containing Lactobacillus rhamnosus DR20. Appl Environ Microbiol. 2000;66(6):2578-88.

38. Vanhoutte T, Huys G, Brandt E, Swings J. Temporal stability analysis of the microbiota in human feces by denaturing gradient gel electrophoresis using universal and group-specific 16S rRNA gene primers. FEMS Microbiol Ecol. 2004;48(3):437-46

39. Zoetendal EG, Akkermans AD, De Vos WM. Temperature gradient gel elec trophoresis analysis of $16 \mathrm{~S}$ rRNA from human fecal samples reveals stable and host-specific communities of active bacteria. Appl Environ Microbiol. 1998;64(10):3854-9.

40. Walter J, Hertel C, Tannock GW, Lis CM, Munro K, Hammes WP. Detection of Lactobacillus, Pediococcus, Leuconostoc, and Weissella species in human feces by using group-specific PCR primers and denaturing gradient gel electrophoresis. Appl Environ Microbiol. 2001;67(6):2578-85.

41. Seto CT, Jeraldo P, Orenstein R, Chia N, DiBaise JK. Prolonged use of a proton pump inhibitor reduces microbial diversity: implications for Clostridium difficile susceptibility. Microbiome. 2014;2:42

42. Tsuda A, Suda W, Morita H, Takanashi K, Takagi A, Koga Y, Hattori M. Influence of proton-pump inhibitors on the luminal microbiota in the gastrointestinal tract. Clin Transl Gastroenterol. 2015;6:e89.

43. Dodd HM, Gasson MJ. Bacteriocins of lactic acid bacteria. In: Gasson MJ, de Vos WM, editors. Genetics and biotechnology of lactic acid bacteria. London: Blackie Academic and Professional; 1994. p. 211-55.

44. Langhendries JP, Detry J, Van Hees J, Lamboray JM, Darimont J, Mozin MJ, Secretin MC, Senterre J. Effect of a fermented infant formula containing viable Bifidobacteria on the faecal flora composition and $\mathrm{pH}$ of healthy full-term infants. J Pediatr Gastroenterol Nutr. 1995;21(2):177-81.

45. Kailasapathy K, Chin J. Survival and therapeutic potential of probiotic organisms with reference to Lactobacillus acidophilus and Bifidobacterium spp. Immunol Cell Biol. 2000;78(1):80-8.

46. Rolfe RD. The role of probiotic cultures in the control of gastrointestinal health. J Nutr. 2000;130(2):396S-402S.

47. Beasley SB, Saris PEJ. Nisin-producing Lactococcus lactis strains isolated from human milk. Appl Environ Microbiol. 2004;70(8):5051-3.

48. Siegumfeldt H, Björn Rechinger K, Jakobsen M. Dynamic changes of intracellular $\mathrm{pH}$ in individual lactic acid bacterium cells in response to a rapid drop in extracellular pH. Appl Environ Microbiol. 2000:66(6):2330-5.

49. Zheng W, Zhang Y, Lu HM, Li DT, Zhang ZL, Tang ZX, Shi LE. Antimicrobial activity and safety evaluation of Enterococcus faecium KQ 2.6 isolated from peacock feces. BMC Biotechnology. 2015;15:30.

50. Buydens P, Debeuckelaere S. Efficacy of SF 68 in the treatment of acute diarrhea. A placebo-controlled trial. Scand J Gastroenterol. 1996;31(9):887-91.
51. Wunderlich PF, Braun L, Fumagalli I, D’Apuzzo V, Heim F, Karly M, Lodi R, Politta G, Vonbank F, Zeltner L. Double-blind report on the efficacy of lactic acid-producing Enterococcus SF68 in the prevention of antibioticassociated diarrhea and in the treatment of acute diarrhea. J Int Med Res. 1989;17(4):333-8.

52. Starke IC, Zentek J, Vahjen W. Effects of the probiotic Enterococcus faecium NCIMB 10415 on selected lactic acid bacteria and enterobacteria in coculture. Benef Microbes. 2015;6(3):345-52.

53. Klingspor S, Bondzio A, Martens H, Aschenbach JR, Bratz K, Tedin K Einspanier R, Lodemann U. Enterococcus faecium NCIMB 10415 modulates epithelial integrity, heat shock protein, and proinflammatory cytokine response in intestinal cells. Mediators Inflamm. 2015. https://doi. org/10.1155/2015/304149 (Epub 2015 Apr 8).

54. Bednorz C, Guenther S, Oelgeschläger K, Kinnemann B, Pieper R, Hartmann S, Tedin K, Semmler T, Neumann K, Schierack P, Bethe A, Wieler LH. Feeding the probiotic Enterococcus faecium strain NCIMB 10415 to piglets specifically reduces the number of Escherichia coli pathotypes that adhere to the Gut Mucosa. Appl Environ Microbiol. 2013;79(24):7896-904.

55. Russo TA, Johnson JR. Proposal for a new inclusive designation for extraintestinal pathogenic isolates of Escherichia coli: ExPEC. J Infect Dis. 2000;181(5):1753-4

56. Kaper JB, Nataro JP, Mobley HL. Pathogenic Escherichia coli. Nat Rev Microbiol. 2004;2(2):123-40.

57. Ganas P, Liebhart D, Glösmann M, Hess C, Hess M. Escherichia coli strongly supports the growth of Histomonas meleagridis, in a monoxenic culture, without influence on its pathogenicity. Int J Parasitol. 2012:42(10):893-901.

58. Dunn LA, Boreham PF, Stenzel DJ. Ultrastructural variation of Blastocystis hominis stocks in culture. Int J Parasitol. 1989;19(1):43-56.

59. Rezania S, Amirmozaffari N, Tabarraei B, Jeddi-Tehrani M, Zarei O, Alizadeh R, Masjedian F, Zarnani AH. Extraction, purification and characterization of lipopolysaccharide from Escherichia coli and Salmonella typhi. Avicenna J Med Biotechnol. 2011;3(1):3-9.

60. Hager CL, Ghannoum MA. The mycobiome: role in health and disease, and as a potential probiotic target in gastrointestinal disease. Dig Liver Dis. 2017:49(11):1171-6.

61. Moyes DL, Wilson D, Richardson JP, Mogavero S, Tang SX, Wernecke J, Höfs S, Gratacap RL, Robbins J, Runglall M, Murciano C, Blagojevic M, Thavaraj S, Förster TM, Hebecker B, Kasper L, Vizcay G, lancu SI, Kichik N, Häder A, Kurzai O, Luo T, Krüger T, Kniemeyer O, Cota E, Bader O, Wheeler RT, Gutsmann T, Hube B, Naglik JR. Candidalysin is a fungal peptide toxin critical for mucosal infection. Nature. 2016:532(7597):64-8.

62. Konno N, Ishii M, Nagai A, Watanabe T, Ogasawara A, Mikami T, Matsumoto T. Mechanism of Candida albicans transformation in response to changes of pH. Biol Pharm Bull. 2006;29(5):923-6.

63. Sherrington SL, Sorsby E, Mahtey N, Kumwenda P, Lenardon MD, Brown I, Ballou ER, MacCallum DM, Hall RA. Adaptation of Candida albicans to environmental $\mathrm{pH}$ induces cell wall remodelling and enhances innate immune recognition. PLoS Pathog. 2017;13(5):e1006403.

64. Morales DK, Hogan DA. Candida albicans interactions with bacteria in the context of human health and disease. PLoS Pathog. 2010;6(4):e1000886.
Ready to submit your research? Choose BMC and benefit from:

- fast, convenient online submission

- thorough peer review by experienced researchers in your field

- rapid publication on acceptance

- support for research data, including large and complex data types

- gold Open Access which fosters wider collaboration and increased citations

- maximum visibility for your research: over $100 \mathrm{M}$ website views per year

At BMC, research is always in progress.

Learn more biomedcentral.com/submissions 